high (Kass, 1960 ; Turner, 1961 ; Kincaid-Smith et al., 1964). Repeated or persistent infection is held to be the major factor in the development of chronic pyelonephritis (Brumfitt and Percival, 1964), and it is hoped that by the detection and treatment of acute or unsuspected infections the incidence of chronic renal failure may be reduced.

This study of a group of non-pregnant women has shown that the incidence of unsuspected infection (5.3\%) is similar to that found in pregnant women. The detection of these infections is relatively simple, and the screening of all women attending gynaecological outpatient departments and the treatment of those infected may be of value. Though some variation in incidence was found in differing gynaecological conditions, infections were present in all groups. The incidence among women whose prime complaint was infertility was higher than that found in pregnancy and similar to the incidence of $8 \%$ mentioned by Sleigh et al. (1964).

The organisms causing the infections were similar to those in bacteriuria of pregnancy, with $E$. coli predominating. A higher incidence of pyuria was present, however, among gynaecological patients than in pregnancy bacteriurias (Williams et al., 1965).

In the majority of cases a short course of a sulphonamide was sufficient to clear the infection, and ampicillin cured many of those failing to respond to sulphonamides. Only $12(18 \%)$ of the 66 patients closely followed up proved resistant to treatment, and eight of these had abnormal pyelograms. Among those who responded to simple therapy, abnormalities were also found on pyelography, but they were usually of minor importance, and it was among the more resistant infections that the major disease, such as the presence of calculus, was found. The short courses of treatment given in this study helped us to discover those patients whose severe underlying renal disease failed to respond to the simpler measures.

The role which asymptomatic infection plays in the development of progressive renal damage is not clear, but the presence of infection, often associated with hypertension, is a pointer to existing renal disease needing treatment.

Though treatment is easy to administer the follow-up of these patients is difficult within the resources of gynaecological clinics. The amount of occult renal disease found in this survey, however, suggests that consideration be given to the provision of facilities for urine screening and adequate follow-up.

\section{REFERENCES}

Brumfitt, W., and Percival, A. (1964). F. clin. Path., 37, 482.

Kass, E. H. (1956). Trans. Ass. Amer. Phycns, 69, 56.

Kass, E. H. (1960) Arch. intern. Med., 105, 194.

Kincaid-Smith, P., and Bullen, M. (1965). Lancet, 1, 395.

Kincaid-Smith, P., Bullen, M., Mills, J., Fussell, U., Huston, N., and Goon, F.'(1964). Lancet, $2,61$.

Leigh, D. A., and Williams, J. D. (1964). 7. clin. Path., 17, 498.

Sleigh, J. D., Robertson, J. G., and Isdale, M. H. (1964). F. Obstet. Gynaec. Brit. Cwlth, 71, 74.

Turner, G. C. (1961). Lancet, 2, 1062.

Williams, J. D., Leigh, D. A., Rosser, E. ap I., and Brumfitt, W. (1965)

f. Obstet. Gynaec. Brit. Cwlth, 72, 327.

\title{
Effect of Salbutamol on Spirometry and Blood-gas Tensions in Bronchial Asthma
}

\author{
K. N. V. PALMER,* M.D., F.R.C.P., M.R.C.P.ED. ; M. L. DIAMENT, $\dagger$ M.D.
}

\begin{abstract}
Cummary : A new bronchodilator drug, salbutamol, $S$ reduced airway obstruction in 37 patients with bronchial asthma but did not lead to a significant fall in lowered arterial oxygen tension. This drug, unlike other bronchodilators, appears to have little or no effect on the cardiovascular system, and it is suggested that it does not therefore lead to an intensification of the ventilation/perfusion disturbance in the lung leading to a worsening of hypoxaemia.
\end{abstract}

\section{Introduction}

Sympathomimetic drugs are much used to reverse or decrease the widespread small airway obstruction which characterizes attacks of bronchial asthma. However, deaths from asthma have risen progressively during the past decade, and the increase in the use of pressurized aerosols, most often containing isoprenaline, correlates closely with the increase in asthma mortality in Britain (Speizer et al., 1968). Isoprenaline is a powerful stimulant of $\beta$-adrenergic receptors in both bronchial and cardiac muscle, so that in addition to relaxing the smooth muscle of the bronchi it increases cardiac output and dilates the pulmonary vasculature (Aviado and Schmidt, 1957). Probably as a direct consequence of its action on the cardio-

* Reader in Medicine, University of Aberdeen.

† Lecturer in Physiology, University of Aberdeen. vascular system, even though airway obstruction is diminished, there may be no increase in lowered arterial oxygen tensions, and indeed in many instances the degree of hypoxaemia may become worse afterwards (Knudson and Constantine, 1967 ; Field, 1967 ; Palmer and Diament, 1967). The decrease in arterial oxygen saturation in patients already hypoxaemic as a result of the asthma attack is clearly undesirable; moreover, it has been suggested that the stimulant effect of isoprenaline on the hypoxaemic myocardium may lead to ventricular irritability and fatal arrhythmia (Speizer et al., 1968).

We report here the effect, when given by aerosol inhalation, of a new selective $\beta$-adrenergic stimulant (salbutamol) on spirometric and blood-gas tension measurements in asthmatic subjects. This drug is a potent and long-lasting stimulator of $\beta$-adrenergic receptors in bronchial muscle, but has relatively little effect on the cardiovascular system (Brittain et al., 1968), and might therefore be expected to reduce increased airway resistance without a concomitant fall in $\mathrm{PaO}_{2}$.

\section{Patients and Methods}

Thirty-seven patients were investigated. Their mean age was 45.6 years $( \pm 14.0)$. They had been admitted to hospital in status asthmaticus and had a long history of attacks of acute airway obstruction with little or no disability between attacks. All had either blood or sputum eosinophilia, and the majority had both. Blood samples were obtained in a heparin-lubricated 
Effect of Control and Salbutamol Aerosol Inhalation on Blood-gas Tensions and Spirometry in Bronchial Asthma (37 Patients)

\begin{tabular}{|c|c|c|c|c|c|c|}
\hline Measurement & & $\begin{array}{c}\text { Before Control } \\
\text { Inhalation }\end{array}$ & $\begin{array}{l}\text { After Control } \\
\text { Inhalation }\end{array}$ & Difference & $\begin{array}{c}\text { After } \\
\text { Salbutamol }\end{array}$ & Difference \\
\hline $\begin{array}{ll}\text { F.V.C. (1. A.T.P.S.) } & \\
\text { F.E.V.1 (1.A.T.P.S.) } \\
\text { F.E.V.1 (\%) } & \ldots \\
\mathrm{PaO}_{2}(\mathrm{~mm} . \mathrm{Hg}) & \ldots \\
\mathrm{PaCO}_{2}(\mathrm{~mm} . \mathrm{Hg}) & \ldots\end{array}$ & 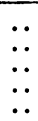 & $\begin{array}{l}2 \cdot 71( \pm 1 \cdot 21) \\
1 \cdot 48( \pm 0 \cdot 77) \\
53 \cdot 3( \pm 9 \cdot 2) \\
82 \cdot 5( \pm 12 \cdot 5) \\
41 \cdot 2( \pm 8 \cdot 2)\end{array}$ & $\begin{array}{l}2.70( \pm 1 \cdot 20) \\
1.49( \pm 0.81) \\
53 \cdot 1( \pm 10.3) \\
=\end{array}$ & $\begin{array}{l}-0.01 \text { (N.S.) } \\
+0.01 \text { (N.S.) } \\
-0.2 \text { (N.S.) } \\
=\end{array}$ & $\begin{array}{l}3 \cdot 13( \pm 1 \cdot 20) \\
1 \cdot 83( \pm 0 \cdot 86) \\
56 \cdot 6( \pm 11 \cdot 1) \\
80 \cdot 6( \pm 12 \cdot 6) \\
40 \cdot 5( \pm 7 \cdot 9)\end{array}$ & $\begin{array}{l}+0.43(\mathrm{P}<0.001) \\
+0.34(\mathrm{P}<0.001) \\
+3.5(\mathrm{P}<0.001) \\
-1.9 \text { (N.S.) } \\
-0.7 \text { (N.S.) }\end{array}$ \\
\hline
\end{tabular}

syringe from the brachial artery when the patient was breathing air at the start of the experiment and five minutes after the aerosol inhalation of $200 \mathrm{mg}$. of salbutamol (which is equivalent to $0.8 \mathrm{mg}$. of isoprenaline sulphate), and $\mathrm{PaO}_{2}$ and $\mathrm{PaCO}_{2}$ were measured in duplicate by means of electrodes manufactured by Radiometer, Copenhagen. The standard deviation of a single measurement with these electrodes in our hands was $1.7 \mathrm{~mm}$. $\mathrm{Hg}$ for the oxygen electrode and $1.2 \mathrm{~mm}$. $\mathrm{Hg}$ for the carbon dioxide electrode. Forced expiratory spirograms (F.E.S.) were obtained before and five minutes after a control inhalation of an aerosol containing only the propellant gas and again five minutes after the aerosol inhalation of $200 \mathrm{mg}$. of salbutamol. In each case the aerosol was released by the investigator from residual volume. From the spirograms the forced vital capacity (F.V.C.), the forced expiratory volume in 1 second (F.E.V..$_{1}$, and the F.E.V. $\cdot_{1}$ as a percentage of the F.V.C. (F.E.V. ${ }_{1} \%$ ) were calculated. The measurements were recorded in litres at A.T.P.S. (ambient temperature and pressure saturated with water vapour).

\section{Results}

Results of the spirometric and blood-gas tension measurements are shown in the Table. At the beginning of the experiment the F.V.C., F.E.V. ${ }_{1}$, and F.E.V. ${ }_{1} \%$ were all much reduced, and there was hypoxaemia without hypercapnia-changes which are characteristic of an asthma attack of moderate severity. Following the control inhalation there was no change in the spirometric measurements, but after salbutamol there was a significant increase in F.V.C., F.E.V..$_{1}$, and F.E.V..$_{1} \%$. After salbutamol there were insignificant falls of $1.9 \mathrm{~mm}$. $\mathrm{Hg}$ in $\mathrm{PaO}_{2}$ and $0.7 \mathrm{~mm}$. $\mathrm{Hg}$ in $\mathrm{PaCO}_{2}$ respectively.

\section{Discussion}

These asthmatic subjects had asthma of moderate severity. There was no change in the F.E.S. following the control inhalation, but there were highly significant changes in F.V.C., F.E.V..$_{1}$, and F.E.V..$_{1} \%$ after salbutamol, indicating a reduction in airway obstruction and lung hyperinflation. However, in spite of this improvement in ventilation there was no significant intensification of the hypoxaemia, the fall in $\mathrm{PaO}_{2}$ being only $1.9 \mathrm{~mm}$. Hg, whereas mean falls of $8.7 \mathrm{~mm}$. $\mathrm{Hg}$ (Knudson and Constantine, 1967) have been reported in comparable asthmatic subjects after aerosol isoprenaline. The fall in $\mathrm{PaO}_{2}$ after isoprenaline is attributed to an intensification of ventilation/perfusion disturbance in the lung due to increased pulmonary blood flow consequent on the increase in cardiac output, and possibly in addition to reversal of hypoxic-induced pulmonary vasoconstriction.

In the experimental animal the stimulant effect of salbutamol on the cardiovascular system was 2,000 times less than that of isoprenaline, and its vasodilator action was only about $1 / 10$ that of isoprenaline (Brittain et al., 1968). It seems likely, therefore, that because salbutamol has a minimal effect on the cardiovascular system compared with isoprenaline undesirable lowering of $\mathrm{PaO}_{2}$, even though airway obstruction is much reduced, does not occur. Nevertheless, though $\mathrm{PaO}_{2}$ did not fall after the drug, it did not rise even though ventilatory function was much improved. We have suggested that after aerosol isoprenaline it is only when there is a considerable reduction in the degree of hyperinflation of the lung, as shown by an increase in F.V.C. of greater than $20 \%$, that any improvement in $\mathrm{PaO}_{2}$ can be expected (Palmer and Diament, 1968). In this study the rise in F.V.C. after salbutamol was $15.9 \%$, so presumably these subjects did not improve sufficiently in this respect to allow for a rise in the $\mathrm{PaO}_{2}$.

We conclude that salbutamol is a useful bronchodilator drug, which because it appears to have little or no effect on the cardiovascular system may have advantages over isoprenaline. However, because of the known variability of asthmatic patients' response to bronchodilator drugs this could be best established by a comparison between isoprenaline and salbutamol in the same patient.

Our thanks are due to Dr. W. T. Simpson, head of medical services, Messrs. Allen \& Hanburys, for supplies of salbutamol, and to Miss Fiona Fiddes for technical assistance.

Requests for reprints should be addressed to Dr. K. N. V. Palmer, University Department of Medicine, Foresterhill, Aberdeen, AB9 2ZD.

\section{REFERENCES}

Aviado, D. M., and Schmidt, C. F. (1957). F. Pharmacol. exp. Ther., 120, 512 .

Brittain, R. T., Farmer, J. B., Jack, D., Martin, L. E., and Simpson, W. T. (1968). Nature (Lond.), 219, 862.

Field, G. B. (1967). Clin. Sci., 32, 279.

Knudson, R J., and Constantine, H. P. (1967). F. appl. Physiol., 22, 402. Palmer, K N. V., and Diament, M. L. (1967). Lancet, 2, 1232. Palmer, K. N. V., and Diament, M. L. (1968). Lancet, 1, 1372. Speizer, F. E., Doll, R., and Heaf, P. (1968). Brit. med. f., 1, 335. 